\title{
Assessing Magnetic Susceptibility Profiles of Topsoils under Different Occupations
}

\author{
N. Bouhsane $(D)$ and S. Bouhlassa \\ Laboratory of Radiochemistry and Nuclear Chemistry, Department of Chemistry, Mohammed V University, Faculty of Sciences Rabat, \\ 4 Avenue Ibn Battouta, BP 1014 RP, Rabat, Morocco \\ Correspondence should be addressed to N. Bouhsane; naimabouhsane@gmail.com
}

Received 30 April 2018; Revised 30 July 2018; Accepted 9 October 2018; Published 18 October 2018

Academic Editor: Rudolf A. Treumann

Copyright (C) 2018 N. Bouhsane and S. Bouhlassa. This is an open access article distributed under the Creative Commons Attribution License, which permits unrestricted use, distribution, and reproduction in any medium, provided the original work is properly cited.

Magnetic susceptibility measurements at low and high frequencies $\left(\chi_{\mathrm{lf}}, \chi_{\mathrm{hf}}\right)$ were carried out on topsoil samples from reforested, cultivated, and pasture lands from a catchment located at the north of Morocco. The aims of this study were to investigate the impact of land use or human activity on $\chi_{\mathrm{lf}}$ of soil overlying the same substrate, to discriminate allochthonous material or pollution from autochthonous or inherited ones, and to assess the origin and contribution of superparamagnetic (SP) grains to the global magnetic susceptibility $\chi_{\mathrm{lf}}$. Measurements of $\chi_{\mathrm{lf}}$ indicated significant enhancement, with values ranging from 12.4 to $252.82 \times 10^{-8} \mathrm{~m}^{3} \mathrm{~kg}^{-1}$ with a mean value of $107.087 \times 10^{-8} \mathrm{~m}^{3} \mathrm{~kg}^{-1}$ for the reforested lands. In the cultivated lands, $\chi_{\mathrm{lf}}$ were from 8.4 to $88.65 \times 10^{-8} \mathrm{~m}^{3} \mathrm{~kg}^{1}$ with a mean value of $42.69 \times 10^{-8} \mathrm{~m}^{3} \mathrm{~kg}^{-1}$, while in the pasture lands, $\chi_{\mathrm{lf}}$ was comprised between $14.34 \times 10^{-8} \mathrm{~m}^{3} \mathrm{~kg}^{-1}$ and $133.35 \times$ $10^{-8} \mathrm{~m}^{3} \mathrm{~kg}^{-1}$ with a mean value of $57.33 \times 10^{-8} \mathrm{~m}^{3} \mathrm{~kg}^{-1}$. The magnetic enhancement indicates high concentration of ferrimagnetic minerals in the top soil. The magnetic susceptibility enhancement decreases as the human activity increases, while the underlying bedrock is almost the same: reforested land > pastures land > cultivated land. The analysis of the variations of $\chi_{\mathrm{lf}}$ and frequency dependent susceptibilities $\left(\chi_{\mathrm{fd}}\right.$ and $\left.\% \chi_{\mathrm{fd}}\right)$, along the profiles of soil, indicate a pedogenic origin of the topsoil magnetic susceptibility enhancement.

\section{Introduction}

Magnetic properties of soils reflect soil magnetic mineralogy composition and size [1]. The minerals of soil, which control magnetic susceptibility, can in principle originate from three main sources: lithogenic derived from parent material, pedogenic due to physical, chemical and biological processes in soils, and the anthropogenic mostly spherical industrial particulate [2]. Concentration of iron oxides and thus the soil magnetic susceptibility profile is mainly influenced by not only its parent material, physicochemical properties, age, temperature, biological activity, and pedogenic processes, but also by human activities [3].

Magnetic susceptibility (MS), the ratio of induced magnetization to an applied magnetic field, is a function of strongly magnetic particle concentrations, grain sizes, grain shapes, and mineralogy [2]. Field measurements of MS (volume susceptibility) are typically reported in dimensionless units (e.g., $10^{-5}$ (SI units)), whereas laboratory measurements of mass specific susceptibility are reported in mass-based units (e.g., $10^{-8} \mathrm{x} \mathrm{m}^{3} \mathrm{~kg}^{-1}$ (SI units)), equivalent to volume susceptibility divided by density [4]. Owing to the strong contribution of iron minerals to magnetic susceptibility, their presence in most soils, and the effect of biophysical environment on them, a growing attention has been paid to magnetic susceptibility as a means to facilitate the understanding of soil and landscapes transformations $[2,4,5]$.

Fialova et al. [6] show that magnetic properties of soils from regions with different geological and environmental settings are influenced primarily by lithology while different soil types play apparently no role, even though Hanesh et al. [7] reported that soil type and lithology are closely interrelated and both influence MS measured in the soil. As the bedrock determines mainly the soil type and influences strongly the MS, especially in the areas with weak or no anthropogenic activity, it would be potentially possible to discriminate the impact of human activity on topsoil MS. That would be reached by simple comparison of MS recorded 


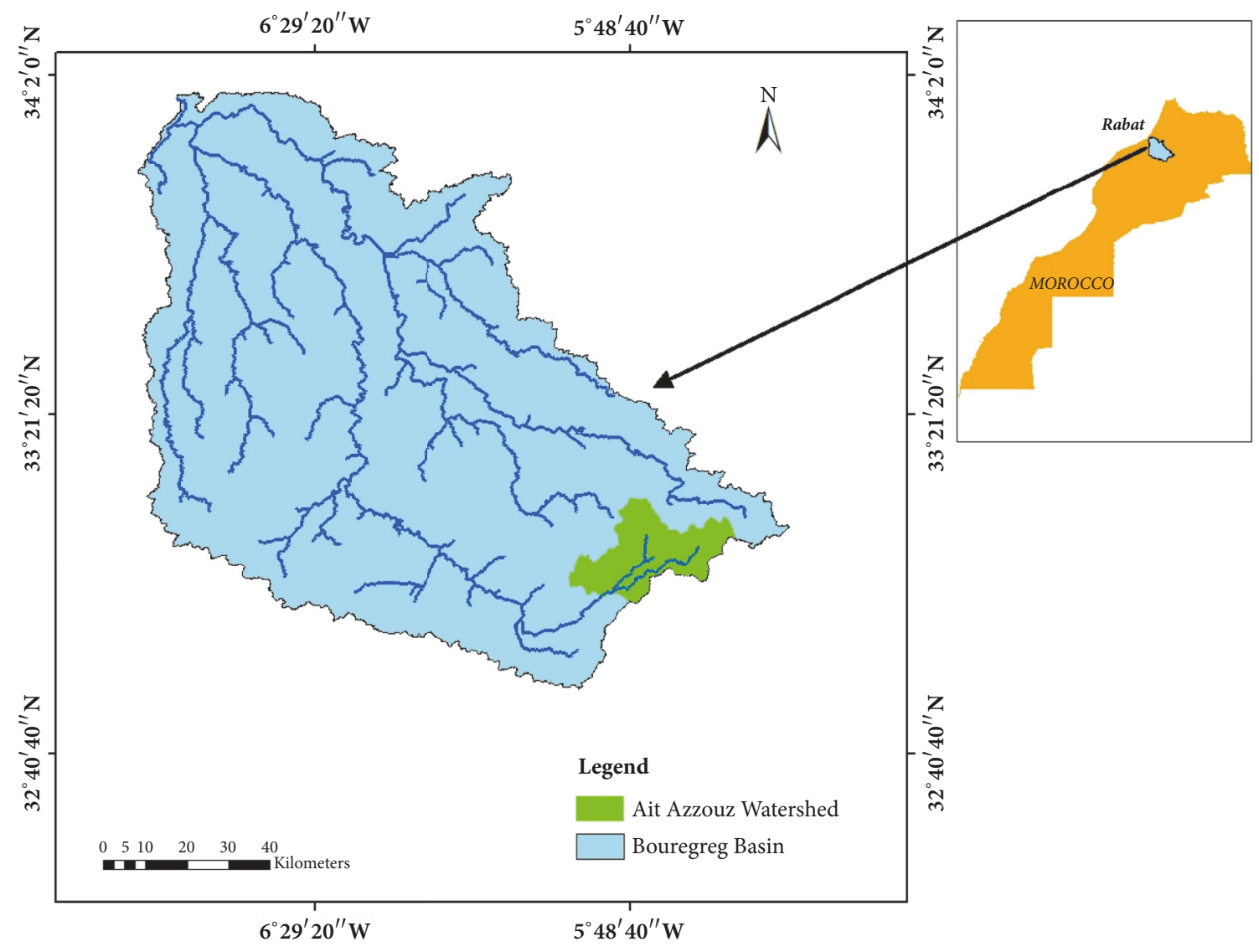

FIGURE 1: Geographical localization of the study area.

on top soil overlying the same parent material or bedrock with low MS. This objective will constitute the aim of the study which focuses on the detailed comparison of some magnetic proxies (MS, mass specific frequency dependence susceptibility $\chi_{\mathrm{fd}}$, and percent frequency dependent susceptibility $\left.\left(\chi_{\mathrm{fd}} \%\right)\right)$ measured on reforested, cultivated, and pasture lands to (i) discriminate the impact of human activity, (ii) analyze the magnetic mineralogy grain size, (iii) distinguish the neoformed magnetic mineral from allochthonous one or pollution, and finally (iv) establish the origin of topsoil MS enhancement.

\section{Materials and Methods}

2.1. Study Area. Ait Azzouz basin, selected for the study, is a subcatchment of the Bouregreg watershed (Figure 1). It is located at $32^{\circ} 70^{\prime}-33^{\circ} \mathrm{N}$ and $5^{\circ} 70^{\prime}-5^{\circ} 08^{\prime} \mathrm{W}$, in the north of Morocco near Rabat the capital, with an area of $195 \mathrm{~km}^{2}$. Shaped in the Asfar Plain of Moroccan Central Plateau, it constitutes one of the most important watersheds in upstream of Wadi Grou. The climate of the region is semiarid with average yearly precipitations of $400 \mathrm{~mm}$ and annual air temperature varying between $11^{\circ} \mathrm{C}$ as a minimum and $22^{\circ} \mathrm{C}$ as a maximum. It is generally characterized by a wet period from October to February and a dry one the rest of the year. The vegetation is variable, dominated by cedar picketing and the cultivated lands. The reforested areas represent a small area. The watershed has a variable lithology: schist, quartzite, sandstone, limestone, and microgranite conglomerate. At the north and east the Viséens conglomerates outcrop and on the west we find the quartzite ridges. Chromic luvisol is the predominant soil type in the watershed [8].

2.2. Sampling and Analysis. Different sites were selected and sampled in reforested land, cultivated land and pasture land, respectively. The cultivated soil was marked as AZC soil, the pastures were marked as AZP soil, and the reforested soil was marked as AZR soil. Three sites in the reforested soils (AZR1, AZR11, and AZR14), four sites in the cultivated soils (AZC3, AZC9, AZC10, and AZC12), and six sites in the pastures soils (AZP2, AZP4, AZP5, AZP6, AZP8, and AZP16) were selected. The samples characteristics are given in Table 1. At each sampling site, a core with $35 \mathrm{~cm}$ depth and $6 \mathrm{~cm}$ in diameter was collected and divided in layers of $5 \mathrm{~cm}$ length. The superficial areas of each soil sample that were in direct contact with the metal corer were shaved off using a plastic knife to avoid the potential pollution from the coring devices made of iron [9]. There were 62 soil samples collected in total at the 13 sampling sites. Soil samples were oven dried at $40^{\circ} \mathrm{C}$ for $8 \mathrm{~h}$ with good air circulation and no hotspots and then passed through a $1 \mathrm{~mm}$ plastic sieve. All samples were packed individually into cubical boxes of $8 \mathrm{~cm}^{3}$ and measured 
TABLE 1: Characteristics of the sampled sites.

\begin{tabular}{|c|c|c|c|c|}
\hline Sample & Position & Lithology & Vegetal cover & Slope $\%$ \\
\hline AZR14 & $33^{\circ} 07^{\prime} 11^{\prime \prime} \mathrm{N} ; 05^{\circ} 48^{\prime} 19^{\prime \prime} \mathrm{W}$ & Schist and quartzite & Dense forest & 40 \\
\hline AZR11 & $33^{\circ} 04^{\prime} 31^{\prime \prime} \mathrm{N} ; 05^{\circ} 44^{\prime} 54^{\prime \prime} \mathrm{W}$ & Schist and limestone & Residual forest & 45 \\
\hline AZR1 & $33^{\circ} 10^{\prime} 43^{\prime \prime} \mathrm{N} ; 05^{\circ} 48^{\prime} 44^{\prime \prime} \mathrm{W}$ & Schist and limestone & Residual forest & 22 \\
\hline AZP4 & $33^{\circ} 07^{\prime} 56^{\prime \prime} \mathrm{N} ; 05^{\circ} 49^{\prime} 41^{\prime \prime} \mathrm{W}$ & Schist with quartzite & Pasture land & $5-10$ \\
\hline AZP5 & $33^{\circ} 07^{\prime} 56^{\prime \prime} \mathrm{N} ; 05^{\circ} 49^{\prime} 38^{\prime \prime} \mathrm{W}$ & Sandy limestone & Pasture land & 35 \\
\hline AZP6 & $33^{\circ} 05^{\prime} 51^{\prime \prime} \mathrm{N} ; 05^{\circ} 45^{\prime} 33^{\prime \prime} \mathrm{W}$ & Schist and limestone & Pasture land & 15 \\
\hline AZP2 & $33^{\circ} 10^{\prime} 46^{\prime \prime} \mathrm{N} ; 05^{\circ} 46^{\prime} 42^{\prime \prime} \mathrm{W}$ & Schist & Pasture land & 7 \\
\hline AZP8 & $33^{\circ} 04^{\prime} 56^{\prime \prime} \mathrm{N} ; 05^{\circ} 45^{\prime} 97^{\prime \prime} \mathrm{W}$ & Schist & Pasture land & $20-25$ \\
\hline AZP16 & $33^{\circ} 05^{\prime} 07^{\prime \prime} \mathrm{N} ; 05^{\circ} 46^{\prime} 52^{\prime \prime} \mathrm{W}$ & Schist & Pasture land & 5 \\
\hline AZC3 & $33^{\circ} 07^{\prime} 41^{\prime \prime} \mathrm{N} ; 05^{\circ} 49^{\prime} 01^{\prime \prime} \mathrm{W}$ & Schist & Cultivated land & $0-5$ \\
\hline AZC9 & $33^{\circ} 04^{\prime} 54^{\prime \prime} \mathrm{N} ; 05^{\circ} 45^{\prime} 46^{\prime \prime} \mathrm{W}$ & Schist and limestone & Cultivated land & 0 \\
\hline AZC10 & $33^{\circ} 04^{\prime} 31^{\prime \prime} \mathrm{N} ; 05^{\circ} 45^{\prime} 30^{\prime \prime} \mathrm{W}$ & Schist and limestone & Cultivated land & 0 \\
\hline AZC12 & $33^{\circ} 04^{\prime} 59^{\prime \prime} \mathrm{N} ; 05^{\circ} 45^{\prime} 14^{\prime \prime} \mathrm{W}$ & Schist and limestone & Cultivated land & 10 \\
\hline
\end{tabular}

using a Bartington magnetic susceptibility meter (MS2) and dual frequency sensor (MS2B). The specific volume magnetic susceptibility $(\kappa)$ was measured at low $\left(0.47 \mathrm{kHz} ; \kappa_{\mathrm{lf}}\right)$ and high $\left(4.7 \mathrm{kHz} ; \kappa_{\mathrm{hf}}\right)$ frequencies. The bulk density $(\rho)$ of a sample was calculated by dividing mass by volume. The $\chi$ value is proportional to the concentration of ferrimagnetic mineral (magnetite and maghemite). Magnetic susceptibility at lowfrequency $\left(\chi_{\mathrm{lf}}\right)$ was calculated by the following:

$$
\chi_{\mathrm{lf}}=\frac{\kappa_{\mathrm{lf}}}{\rho}
$$

The frequency dependence susceptibility $\left(\chi_{\mathrm{fd}}\right)$ is expressed either as a relative loss of susceptibility by [10]

$$
\chi_{\mathrm{fd}}\left(\mathrm{m}^{3} \mathrm{~kg}^{-1}\right)=\chi_{\mathrm{lf}}-\chi_{\mathrm{hf}}
$$

or as a percentage loss of susceptibility, called percentage frequency dependent susceptibility $\left(\chi_{\mathrm{fd}} \%\right)$, it was calculated as follows:

$$
\chi_{\mathrm{fd}} \%=\frac{\chi_{\mathrm{lf}}-\chi_{\mathrm{hf}}}{\chi_{\mathrm{lf}}} * 100
$$

where $\chi_{\mathrm{lf}}$ and $\chi_{\mathrm{hf}}$ are the low and high frequencies susceptibility, respectively.

This percentage reflects the relative significance of the SP/SSD (superparamgnetic and stable single domain) particles in the entire magnetic signal [9]. $\chi_{\mathrm{fd}}$ is also used to determine the concentration of magnetic small grain size fraction beyond the SP/SD limit [11].

\section{Results and Discussion}

3.1. Magnetic Susceptibilities of Soil under Different Occupations. Tables 2-4 give the values of magnetic susceptibility at low and high frequency $\left(\chi_{\mathrm{lf}}, \chi_{\mathrm{hf}}\right)$, the derived values $\chi_{\mathrm{fd}}$, and $\chi_{\mathrm{fd}} \%$ of samples collected in the study area. In the reforested land, the values of magnetic susceptibility at low frequency varied from 12.4 to $252.82 \times 10^{-8} \mathrm{~m}^{3} \mathrm{~kg}^{-1}$ with a mean value of $107.087 \times 10^{-8} \mathrm{~m}^{3} \mathrm{~kg}^{-1}$. In the cultivated land, $\chi_{\text {lf }}$ susceptibilities are varying from 8.4 to $88.65 \times 10^{-8} \mathrm{~m}^{3} \mathrm{~kg}^{1}$ with a mean value of $42.69 \times 10^{-8} \mathrm{~m}^{3} \mathrm{~kg}^{-1}$, whereas in the pastures land, $\chi_{\mathrm{lf}}$ is ranged between $14.34 \times 10^{-8} \mathrm{~m}^{3} \mathrm{~kg}^{-1}$ and $133.35 \times 10^{-8} \mathrm{~m}^{3} \mathrm{~kg}^{-1}$ with a mean value of $57.33 \times$ $10^{-8} \mathrm{~m}^{3} \mathrm{~kg}^{-1}$.

The Ait Azzouz (AZ) basin soils from reforested land and to some extent from pastures land which present magnetic susceptibility higher than $100 \times 10^{-8} \mathrm{~m}^{3} \mathrm{~kg}^{-1}$ can be considered to be highly magnetic, while those from AZ cultivated land would be moderately magnetic as their magnetic susceptibility is between 10 and $100 \times 10^{-8} \mathrm{~m}^{3} \mathrm{~kg}^{-1}$ [12]. In general, there are many factors that cause magnetic susceptibility variations (MS), such as the differences in lithology (lithogenic/geogenic), soil forming processes (pedogenesis), and anthropogenic contribution of magnetic material $[2,10$, 13]. Saddiki et al. [14] confirmed that the lithology is the main factor contributing to the magnetic susceptibility variation.

High MS values indicate high concentration of ferrimagnetic minerals which could be either neoformed (pedogenic origin), inherited from substratum, or allochthonous. The latter are often from atmospheric pollution fallout (e.g., loess), or polluted dust. The values of the studied soils are very low in comparison to those in industrially polluted areas $[1,6,7,15-17]$.

Although the statistical data base is small (13 independent cores with 62 samples), it suggests however that the mean magnetic susceptibility increases in the following order: $\chi_{\mathrm{lf}}$ cultivated land $<\chi_{\text {lf }}$ pastures land $<\chi_{\text {lf }}$ reforested land.

Pedogenic ferrimagnetic minerals have been found to form by oxidation of $\mathrm{Fe}^{2+}$ in iron-bearing minerals in soils subject to wetting/ drying cycles which are characteristics of the regional climate $[18,19]$. The MS in the top soil would hence reflect the soil type and the parent mineral material. The latter is likely the prevalent factor of enhancement of MS in top soil. Extent and magnitude of the MS enhancement depend more on the bioavailable Fe content of the soils and the neoformation evolution conditions [20] where the physical stability is not the lesser one: it is in favor of neoformation development. 
TABLE 2: Magnetic parameters measured on the different samples of Ait Azzouz reforested land.

\begin{tabular}{|c|c|c|c|c|c|c|}
\hline Sample & Depth $(\mathrm{cm})$ & Lithology & $\chi_{\mathrm{lf}}\left(10^{-8} \mathrm{~m}^{3} \mathrm{~kg}^{-1}\right)$ & $\chi_{\mathrm{hf}}\left(10^{-8} \mathrm{~m}^{3} \mathrm{~kg}^{-1}\right)$ & $\chi_{\mathrm{fd}}\left(10^{-8} \mathrm{~m}^{3} \mathrm{~kg}^{-1}\right)$ & $\chi_{\mathrm{fd}} \%$ \\
\hline $1 \mathrm{AZR}_{1}$ & 0 & \multirow{4}{*}{ Schist and limestone } & 141.1 & 133.5 & 7.6 & 5.38 \\
\hline $1 \mathrm{AZR}_{2}$ & 5 & & 132.99 & 124.1 & 8.89 & 6.68 \\
\hline $1 \mathrm{AZR}_{3}$ & 10 & & 104.97 & 98.41 & 6.56 & 6.24 \\
\hline $1 \mathrm{AZR}_{4}$ & 15 & & 134.32 & 127.69 & 6.63 & 4.93 \\
\hline $11 \mathrm{AZR}_{1}$ & 0 & \multirow{5}{*}{ Schist and limestone } & 14.76 & 14.58 & 0.18 & 1.21 \\
\hline $11 \mathrm{AZR}_{2}$ & 5 & & 14.38 & 14.29 & 0.09 & 0.62 \\
\hline $11 \mathrm{AZR}_{3}$ & 10 & & 16.96 & 16.7 & 0.26 & 1.53 \\
\hline $11 \mathrm{AZR}_{4}$ & 15 & & 12.77 & 12.34 & 0.43 & 3.36 \\
\hline $11 \mathrm{AZR}_{5}$ & 20 & & 12.4 & 12.32 & 0.08 & 0.64 \\
\hline $14 \mathrm{AZR}_{1}$ & 0 & \multirow{5}{*}{ Schist and quartzite } & 159.02 & 151.43 & 7.59 & 4.77 \\
\hline $14 \mathrm{AZR}_{2}$ & 5 & & 190.5 & 179.04 & 11.46 & 6.01 \\
\hline $14 \mathrm{AZR}_{3}$ & 10 & & 252.82 & 237.97 & 14.85 & 5.87 \\
\hline $14 \mathrm{AZR}_{4}$ & 15 & & 171.77 & 159.97 & 11.8 & 6.86 \\
\hline $14 \mathrm{AZR}_{5}$ & 20 & & 140.47 & 127.96 & 12.51 & 8.9 \\
\hline
\end{tabular}

TABLE 3: Magnetic parameters measured on the different samples of Ait Azzouz cultivated land.

\begin{tabular}{|c|c|c|c|c|c|c|}
\hline Sample & Depth $(\mathrm{cm})$ & Lithology & $\chi_{\text {lf }}\left(10^{-8} \mathrm{~m}^{3} \mathrm{~kg}^{-1}\right)$ & $\chi_{\mathrm{hf}}\left(10^{-8} \mathrm{~m}^{3} \mathrm{~kg}^{-1}\right)$ & $\chi_{\mathrm{fd}}\left(10^{-8} \mathrm{~m}^{3} \mathrm{~kg}^{-1}\right)$ & $\chi_{\mathrm{fd}} \%$ \\
\hline $3 \mathrm{AZC}_{1}$ & 0 & \multirow{5}{*}{ Schist } & 88.65 & 83.76 & 4.89 & 5.51 \\
\hline $3 \mathrm{AZC}_{2}$ & 5 & & 78.22 & 73.42 & 4.8 & 6.13 \\
\hline $3 \mathrm{AZC}_{3}$ & 10 & & 83.74 & 78.01 & 5.73 & 6.84 \\
\hline $3 \mathrm{AZC}_{4}$ & 15 & & 79.84 & 75.61 & 4.23 & 5.29 \\
\hline $3 \mathrm{AZC}_{5}$ & 20 & & 86.92 & 81.39 & 5.53 & 6.36 \\
\hline $9 \mathrm{AZC}_{1}$ & 0 & \multirow{4}{*}{ Schist and limestone } & 59.23 & 56.75 & 2.48 & 4.18 \\
\hline $9 \mathrm{AZC}_{2}$ & 5 & & 50.35 & 47.95 & 2.4 & 4.76 \\
\hline $9 \mathrm{AZC}_{3}$ & 10 & & 56.81 & 54.11 & 2.7 & 4.75 \\
\hline $9 \mathrm{AZC}_{4}$ & 20 & & 55.93 & 53.44 & 2.49 & 4.45 \\
\hline $10 \mathrm{AZC}_{1}$ & 0 & \multirow{5}{*}{ Schist and limestone } & 18.32 & 17.88 & 0.44 & 2.4 \\
\hline $10 \mathrm{AZC}_{2}$ & 5 & & 14.67 & 14.26 & 0.41 & 2.79 \\
\hline $10 \mathrm{AZC}_{3}$ & 10 & & 9.65 & 9.57 & 0.08 & 0,82 \\
\hline $10 \mathrm{AZC}_{4}$ & 20 & & 8.79 & 8,64 & 0.15 & 1,7 \\
\hline $10 \mathrm{AZC}_{5}$ & 25 & & 8.4 & 8.31 & 0.09 & 1.07 \\
\hline $12 \mathrm{AZC}_{1}$ & 0 & \multirow{5}{*}{ Schist and limestone } & 25.2 & 24.69 & 0.51 & 2.02 \\
\hline $12 \mathrm{AZC}_{2}$ & 5 & & 27.03 & 26.63 & 0.4 & 1.47 \\
\hline $12 \mathrm{AZC}_{3}$ & 10 & & 32.97 & 31.89 & 1.08 & 3.27 \\
\hline $12 \mathrm{AZC}_{4}$ & 15 & & 13.07 & 12.83 & 0.24 & 1.83 \\
\hline $12 \mathrm{AZC}_{5}$ & 20 & & 13.35 & 12.93 & 0.42 & 3.14 \\
\hline
\end{tabular}

Schist constitutes the same predominant substratum in the sampling area. The mean of magnetic susceptibility (MS) in the reforested land is high compared with cultivated and pastures lands. This difference seems important, as it indicates that the reforested soils are more stable than pastures and cultivated land and may be considered as undisturbed areas due to the density of vegetal cover that protects soil against erosion.

The low values in cultivated soil are likely due to the joint effects of dilution of the magnetic signal by the weakly limestone component of the soils and surface soil stripping by erosion.

Previous studies show that the magnetic susceptibility of soil on marls substrates is generally low. For example, the magnetic susceptibilities of soil on marls in the Nakhla watershed, northern of Morocco, were $\chi_{\mathrm{lf}}>1.1 \mu \mathrm{m}^{3} \mathrm{~kg}^{-1}, 1.1$ $<\chi_{\text {lf }}<0.5 \mu \mathrm{m}^{3} \mathrm{~kg}^{-1}$, and $<0.5 \mu \mathrm{m}^{3} \mathrm{~kg}^{-1}$ in the forested, pastures, and cultivated lands, respectively [21]. Saddiki et al. [14] confirm in the Msoun basin in the Rif area that the mean of magnetic susceptibility of soils is even lower with about 13.5 $\times 10^{-8} \mathrm{~m}^{3} \mathrm{~kg}^{-1}$; the low values have been attributed to high dilution in the soils by dia- and paramagnetic minerals in the marls. The variable, though often with higher magnitudes of magnetic susceptibility in our study in comparison with the data recorded on marly substrates [14, 21], highlights the enlarging impact of schist as prevalent parent material on pedogenic neoformed ferrimagnetic minerals in topsoil though it supports also the dilution of magnetic susceptibility 
TABLE 4: Magnetic parameters measured on the different samples of Ait Azzouz pastures land.

\begin{tabular}{|c|c|c|c|c|c|c|}
\hline Sample & Depth $(\mathrm{cm})$ & Lithology & $\chi_{\mathrm{lf}}\left(10^{-8} \mathrm{~m}^{3} \mathrm{~kg}^{-1}\right)$ & $\chi_{\mathrm{hf}}\left(10^{-8} \mathrm{~m}^{3} \mathrm{~kg}^{-1}\right)$ & $\chi_{\mathrm{fd}}\left(10^{-8} \mathrm{~m}^{3} \mathrm{~kg}^{-1}\right)$ & $\chi_{\mathrm{fd}} \%$ \\
\hline $2 \mathrm{AZP}_{1}$ & 0 & \multirow{5}{*}{ Schist } & 30.88 & 29.18 & 1.7 & 5.5 \\
\hline $2 \mathrm{AZP}_{2}$ & 5 & & 30.06 & 28.62 & 1.44 & 4.79 \\
\hline $2 \mathrm{AZP}_{3}$ & 10 & & 34.17 & 32.32 & 1.85 & 5.41 \\
\hline $2 \mathrm{AZP}_{4}$ & 15 & & 33.13 & 31.28 & 1.85 & 5.58 \\
\hline $2 \mathrm{AZP}_{5}$ & 20 & & 16.24 & 15.81 & 0.43 & 2.64 \\
\hline $4 \mathrm{AZP}_{1}$ & 0 & \multirow{4}{*}{ Schist with quartzite } & 16.51 & 16.08 & 0.43 & 2,6 \\
\hline $4 \mathrm{AZP}_{2}$ & 5 & & 19.99 & 19.24 & 0.75 & 3.75 \\
\hline $4 \mathrm{AZP}_{3}$ & 10 & & 18.55 & 17.85 & 0.7 & 3.77 \\
\hline $4 \mathrm{AZP}_{4}$ & 15 & & 35.65 & 33.88 & 1.77 & 4.96 \\
\hline $5 \mathrm{AZP}_{1}$ & 0 & \multirow{5}{*}{ Sandy limestone } & 53.57 & 49.64 & 3.93 & 7.3 \\
\hline $5 \mathrm{AZP}_{2}$ & 5 & & 37.79 & 34.83 & 2.96 & 7.83 \\
\hline $5 \mathrm{AZP}_{3}$ & 10 & & 29.8 & 27.39 & 2.41 & 8.08 \\
\hline $5 \mathrm{AZP}_{4}$ & 15 & & 35.95 & 33.23 & 2.72 & 7.56 \\
\hline $5 \mathrm{AZP}_{5}$ & 20 & & 14.34 & 13.25 & 1.09 & 7.6 \\
\hline $5 \mathrm{AZP}_{6}$ & 25 & \multirow{6}{*}{ Schist and limestone } & 14.76 & 13.63 & 1.13 & 7.65 \\
\hline $6 \mathrm{AZP}_{1}$ & 0 & & 126.41 & 122.9 & 3.51 & 2.77 \\
\hline $6 \mathrm{AZP}_{2}$ & 5 & & 115.24 & 113.58 & 1.66 & 1.44 \\
\hline $6 \mathrm{AZP}_{3}$ & 10 & & 108.99 & 103.94 & 5.05 & 4.63 \\
\hline $6 \mathrm{AZP}_{4}$ & 15 & & 91.33 & 87.84 & 3.49 & 3.82 \\
\hline $6 \mathrm{AZP}_{5}$ & 20 & & 60.87 & 58.64 & 2.23 & 3.66 \\
\hline $8 \mathrm{AZP}_{1}$ & 0 & \multirow{5}{*}{ Schist } & 94.38 & 89.57 & 4.81 & 5.09 \\
\hline $8 \mathrm{AZP}_{2}$ & 5 & & 105.34 & 101,04 & 4.3 & 4.08 \\
\hline $8 \mathrm{AZP}_{3}$ & 10 & & 128.3 & 124.22 & 4.08 & 3.18 \\
\hline $8 \mathrm{AZP}_{4}$ & 15 & & 119.26 & 115.01 & 4.25 & 3.56 \\
\hline $8 \mathrm{AZP}_{5}$ & 20 & & 133.35 & 126.75 & 6.6 & 4.94 \\
\hline $16 \mathrm{AZP}_{1}$ & 0 & \multirow{4}{*}{ Schist } & 35.03 & 33.59 & 1.44 & 4.11 \\
\hline $16 \mathrm{AZP}_{2}$ & 5 & & 43.78 & 41.35 & 2.43 & 5.55 \\
\hline $16 \mathrm{AZP}_{3}$ & 10 & & 37.52 & 35.91 & 1.61 & 4.29 \\
\hline $16 \mathrm{AZP}_{4}$ & 15 & & 41.64 & 39.41 & 2.23 & 5.35 \\
\hline
\end{tabular}

of schist by clay, mica, or marl contents of the substratum. As the lithology of different sampling sites is closely uniform and the watershed may be considered as being preserved from the industrial pollution, the variations in the values of magnetic susceptibility are likely the result of difference in soil redistribution under different land use. The degree of soil stability under different land uses is correlated with the importance of the formation and accumulation of pedogenetic maghemite in the superficial soil horizons. The pedogenic formation of this ferrimagnetic mineral is favored in well drained soils with low acidity overlying altered or less resistant substratum [18].

Tables 2-4 show that $\chi_{\mathrm{lf}}$ has higher values than $\chi_{\mathrm{hf}}$ in all the soil profile. This difference is due to the presence of superparamagnetic grains with fine size that at high frequency have relaxation times shorter than the measurement time, are blocked magnetically, and do not contribute to the measured signal. In this way the difference indicates the presence of ultrafine ferrimagnetic minerals (grain size less than $0.03 \mu \mathrm{m})[10,22]$. Figure 2 presents $\chi_{\mathrm{lf}}$ versus $\chi_{\mathrm{hf}}$ in reforested cultivated and pastures lands. A high linear correlation between the two parameters with $\mathrm{R}^{2}=0.999$ is observed, and this confirms that pedogenesis of magnetic particles in the sampling area has been active in a similar way.

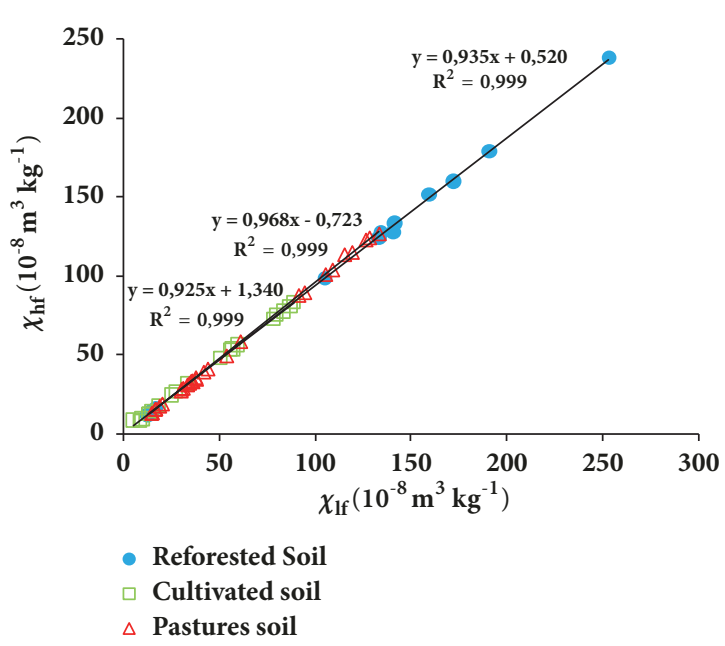

FIGURE 2: Relation between magnetic susceptibility at high and low frequency in the reforested land, cultivated and pastures land.

3.2. Frequency Dependent Magnetic Susceptibility $\left(\chi_{f d}\right)$ Anal$y$ sis. The difference between $\chi_{\mathrm{lf}}$ and $\chi_{\mathrm{hf}}$ can be expressed by the relative loss of susceptibility $\left(\chi_{\mathrm{fd}}\right)$; this difference is 


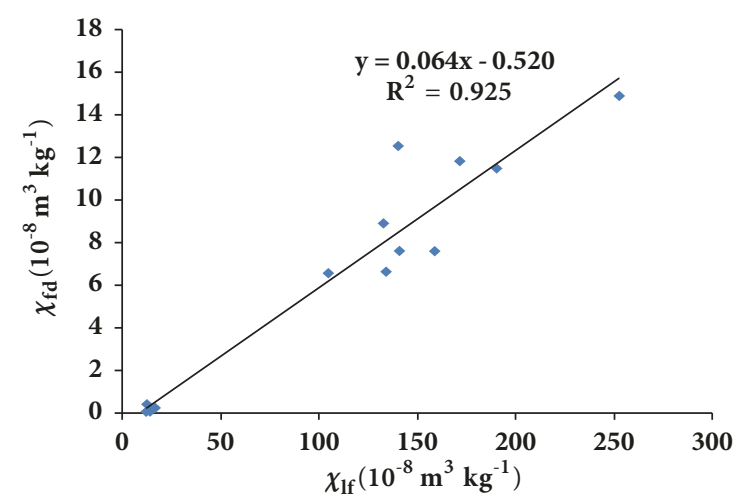

FIgURE 3: Interdependence between $\chi_{\mathrm{fd}}$ and $\chi_{\mathrm{lf}}$ for reforested land.

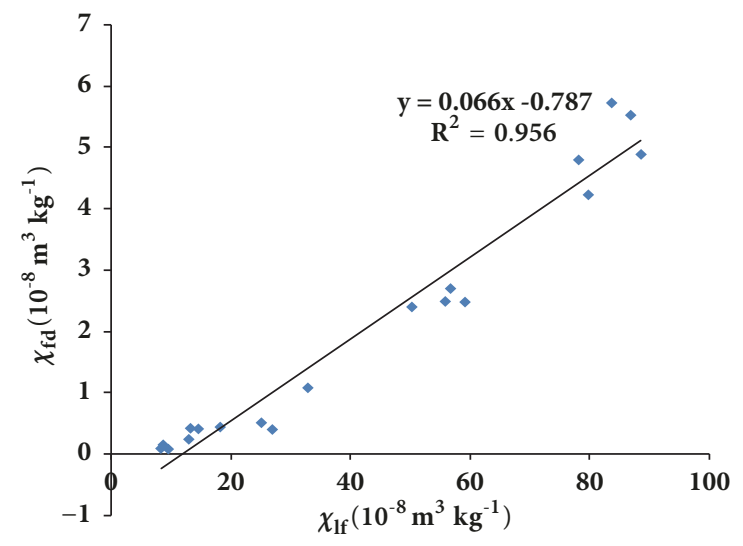

FIGURE 4: Interdependence between $\chi_{\mathrm{fd}}$ and $\chi_{\mathrm{lf}}$ for cultivated land.

important as shown in Tables 2-4. In the reforested soils, $\chi_{\mathrm{fd}}$ ranges from 0.08 and $14.85 \times 10^{-8} \mathrm{~m}^{3} \mathrm{~kg}^{-1}$ with a mean of $6.35 \times 10^{-8} \mathrm{~m}^{3} \mathrm{~kg}^{-1}$, for the cultivated soils, $\chi_{\mathrm{fd}}$ varied between 0.08 to $5.73 \times 10^{-8} \mathrm{~m}^{3} \mathrm{~kg}^{-1}$ with a mean value of 1.98 $\times 10^{-8} \mathrm{~m}^{3} \mathrm{~kg}^{-1}$ and 0.43 to $6.6 \times 10^{-8} \mathrm{~m}^{3} \mathrm{~kg}^{-1}$ with an average of $2.51 \times 10^{-8} \mathrm{~m}^{3} \mathrm{~kg}^{-1}$ for the pastures land. Low values of $\chi_{\mathrm{fd}}$ probably indicate beginning pedogenetic formation of magnetic particles in soils.

3.3. Interdependence between $\chi_{f d}$ and $\chi_{l f}$ and Origin of $M s$ Enhancement. Figures 3-5 are the graphs of $\chi_{\mathrm{fd}}$ versus $\chi_{\mathrm{lf}}$ in the topsoils of Ait Azzouz basin. The magnetic lowfiled susceptibility is positively correlated with mass specific frequency dependent susceptibility. Such linear correlation has been reported by Forster et al. [23] for paleosols on loess substrate where the increasing magnitude of the susceptibility is controlled by the pedogenic (fine grain size) magnetic fraction contribution. A substantial positive correlation between $\chi_{\mathrm{fd}}$ and $\chi_{\mathrm{lf}}$ also shows high homogeneity in the magnetic mineralogy of the soils and particle size despite the change in land use. Sadiki et al. [14] have obtained analogous results. The graph of $\chi_{\mathrm{fd}}$ versus $\chi_{\mathrm{lf}}$ (Figure 6) reporting all the data recorded in the watershed led to the low magnetic susceptibility background $\chi_{\mathrm{b}}$ estimate [23]. $\chi_{\mathrm{b}}$ is obtained by the intersect of $\chi_{\mathrm{lf}}$ axis where $\chi_{\mathrm{fd}}$ is zero. The mean value of the background magnetic susceptibility is $8.12 \times$

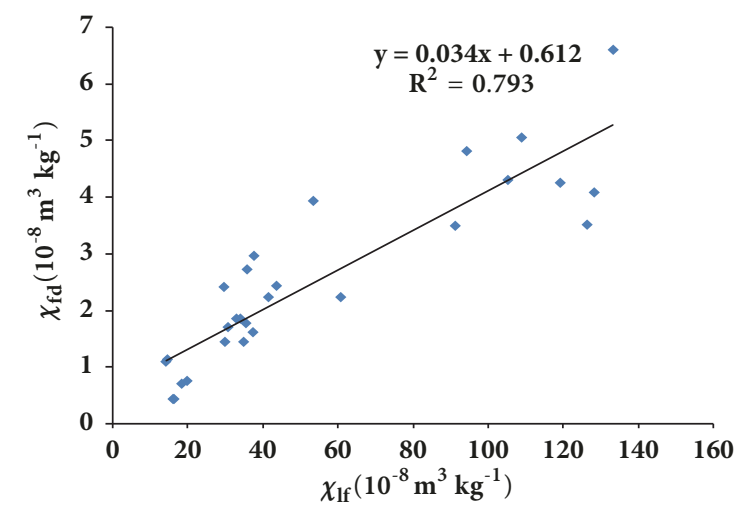

FIGURE 5: Interdependence between $\chi_{\mathrm{fd}}$ and $\chi_{\mathrm{lf}}$ for pastures land.

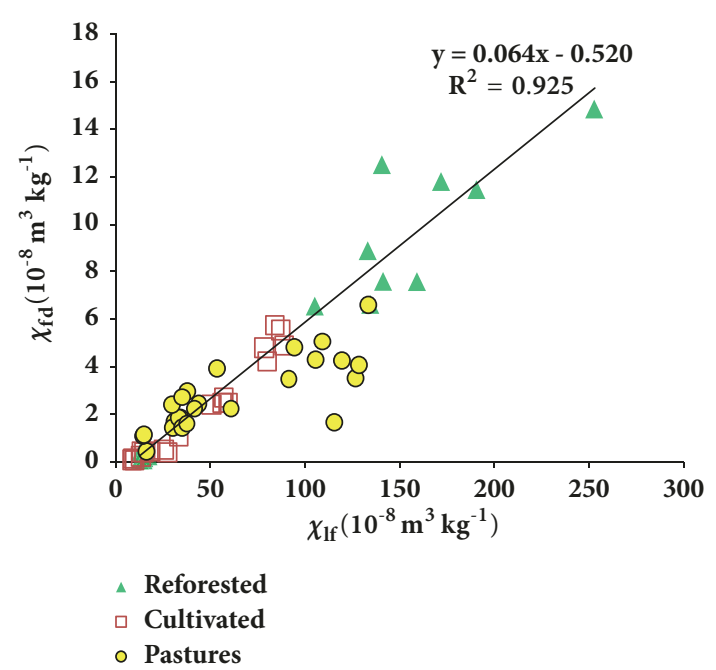

FIgURE 6: $\chi_{\mathrm{fd}}$ versus $\chi_{\mathrm{lf}}$ in the Ait Azzouz watershed.

$10^{-8} \mathrm{~m}^{3} \mathrm{~kg}^{-1}$. This value is very low compared to the mean of $\chi_{\mathrm{lf}}$ values obtained for each land use and is associated with the susceptibility of the unaltered parent material of the soils: the schists, limestones, and quartzites. Consequently, the MS enhancement is attributed to pedogenesis, being consistent with Dearing et al. (1999) analysis and Gautam's [12] soil classification.

3.4. Grain Size Analysis. According to the semiquantitative model proposed by Dearing, [9], the environmental magnetic samples could be classified into four classes: samples with $\chi_{\mathrm{fd}} \%<2 \%$ and SP concentration $<10 \%$ (low SP grains); samples with $\chi_{\mathrm{fd}} \%$ between $2 \%$ and $10 \%$ in which there is a mixture of SP and coarser non SP grains, or SP grains $<0.005 \mu \mathrm{m}$; samples with $\chi_{\mathrm{fd}}$ between $10 \%$ and $14 \%$ and SP concentration $>75 \%$ and samples with $\chi_{\mathrm{fd}}>14 \%$, which represent infrequent values, inexact measurements, or pollution. The magnitudes of the percentage frequency dependent susceptibility $\left(\chi_{\mathrm{fd}} \%\right)$ show that the Ait Azzouz basin soils contain mostly admixture of SP and coarser nonSP grains.

In the reforested land, the value of $\chi_{\mathrm{fd}} \%$ varies between 0.82 and $8.9 \%$ with a mean of $4.5 \%$. 


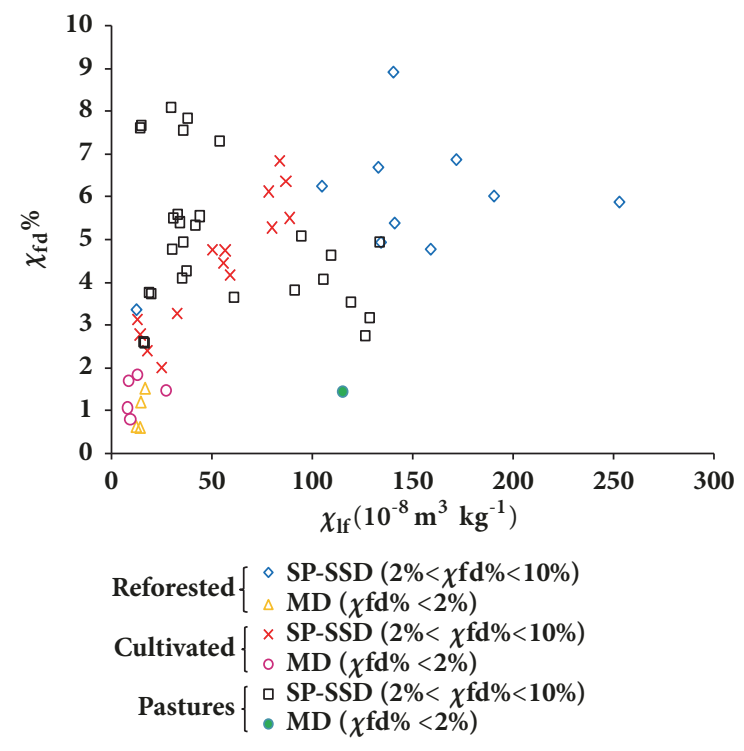

FIGURE 7: Bivariate diagram $\chi_{\mathrm{lf}}-\chi_{\mathrm{fd}} \%$ showing a distribution of magnetic grain sizes in the soils from the reforested soil, cultivated, and pastures soil.

In the cultivated land, five samples fall in the range $<2 \%$ implying that they have no SP grains, while other samples range from 2 to $10 \%$ and may represent a mixture of SP and coarse MD magnetic grain.

For the pastures land, one sample has low $\chi_{\mathrm{fd}} \%$ indicating absence of SP grains, while other samples have medium $\chi_{\mathrm{fd}} \%$ values indicating the presence of mixture of SP and coarser non SP grains.

Generally most of the soil samples in the area contain a mixture of SP and coarser magnetic grains. Figure 7 is the bivariate diagram of $\chi_{\mathrm{lf}}$ and $\chi_{\mathrm{fd}} \%$ for the reforested, cultivated and pastures lands showing the variable susceptibility contribution of the magnetic grain sizes in the soils.

Despite the various lands usage the soils show positive and significant correlation between $\chi_{\mathrm{lf}}$ and $\chi_{\mathrm{fd}} \%$. The positive correlation indicates that the magnetic susceptibility enhancement is due to SP ferrimagnetic grains. The magnetic susceptibility of soils derived from sedimentary rocks usually increases with an increase in frequency dependent susceptibility [17]. Positive correlation between $\chi_{\mathrm{lf}}$ and $\chi_{\mathrm{fd}} \%$ for Chinese loess and paleosol was also reported by many authors [24-26]. The positive correlations recorded within the study area highlight the pedogenic evolution of the top soils.

\section{Conclusions}

This paper presents the results of magnetic susceptibility measurements of soils formed under different land uses in the Ait Azzouz basin, from Morocco. They show significant magnetic susceptibility enhancement related to the neoformation of ferrimagnetic minerals in the soils.

The magnetic measurements of 13 short cores collected from three areas of different land use show that the mean magnetic susceptibility decreases from reforested land to pasture land to cultivated land.
As the underlying bedrock is almost the same throughout the study area and subject to Mediterranean climate with limited wet and extended dry period per year, land use is considered to be the principal factor affecting the physical stability of the soils in the one hand and the geo- and biochemical conditions of evolution and development of pedogenic ferromagnetic mineral on the other hand.

Pedogenesis producing superparamagnetic magnetic minerals seems to be favored in the forest soils and to some extent in the vegetation protected pasture land whereas cultivated soils have the least developed pedogenic magnetic signature.

The variations of $\chi_{\mathrm{lf}}, \chi_{\mathrm{fd}}$ and $\chi_{\mathrm{fd}} \%$ and their correlations demonstrate that: (i) the pedogenetic evolution of the top soil is the fundamental process responsible of the susceptibility enhancement, and (ii) the MS enhancement is fostered especially in preserved reforested areas and lesser in pasture and cultivated land; it seems to decreases with increasing human activity.

The study aims at building up a methodological approach based on magnetic low filed susceptibility measurement to support studies of soil evolution by recognizing neoformed pedogenic magnetic material in topsoils. The studies will have to be accomplished by detailed rock magnetic measurements in order to evaluate the magnetic soil characteristics such as grain size, mineral type and its evolution along the cores and in different land uses qualitatively and quantitatively. (e.g. [27]).

\section{Data Availability}

Due to technical and time constraints, the raw and processing data required to reproduce these findings cannot be shared at this time.

\section{Conflicts of Interest}

The authors declare that they have no conflicts of interest.

\section{Acknowledgments}

The authors would like to thank Pr. Saidati Bouhlassa Director of Laboratory of Radiochemistry and Nuclear Chemistry for his contribution to prepare this manuscript.

\section{References}

[1] T. Magiera, Z. Strzyszcz, A. Kapicka, and E. Petrovsky, "Discrimination of lithogenic and anthropogenic influences on topsoil magnetic susceptibility in Central Europe," Geoderma, vol. 130, no. 3-4, pp. 299-311, 2006.

[2] M. Newson, Environmental magnetism by Roy Thompson and Frank Oldfield, vol. 13, Allen and Unwin, London, UK, 1988.

[3] S. Spassov, R. Egli, F. Heller, D. K. Nourgaliev, and J. Hannam, "Magnetic quantification of urban pollution sources in atmospheric particulate matter," Geophysical Journal International, vol. 159, no. 2, pp. 555-564, 2004.

[4] C. E. Mullins, "Magnetic susceptibility of the soil and its significance in soil science," Journal soil Science, vol. 28, no. 2, pp. 223-246, 1977. 
[5] E. de Jong, D. J. Pennock, and P. A. Nestor, Magnetic susceptibility of soils in different slope positions in Saskatchewan, Canada, vol. 40, Elsevier, Canada, USA, 2000.

[6] H. Fialová, G. Maier, E. Petrovský, A. Kapička, T. Boyko, and R. Scholger, "Magnetic properties of soils from sites with different geological and environmental settings," Journal of Applied Geophysics, vol. 59, no. 4, pp. 273-283, 2006.

[7] M. Hanesch, G. Rantitsch, S. Hemetsberger, and R. Scholger, "Lithological and pedological influences on the magnetic susceptibility of soil: Their consideration in magnetic pollution mapping," Science of the Total Environment, vol. 382, no. 2-3, pp. 351-363, 2007.

[8] M. L. Clark, Using GIS and the RUSLE Model to Create an Index of Potential Soil Erosion at the Large Basin Scale and Discussing the Implications for Water Planning and Land Management in Morocco, University of Texas at Austin, Austin, Texas, USA, 2015.

[9] J. A. Dearing, Environmental magnetic susceptibility using the Bartington MS2 system, Chi Publishing, England, 2nd edition, 1999.

[10] J. A. Dearing, R. J. L. Dann, K. Hay et al., "Frequency-dependent susceptibility measurements of environmental materials," Geophysical Journal International, vol. 124, no. 1, pp. 228-240, 1996.

[11] Q. Liu, J. Torrent, B. A. Maher et al., "Quantifying grain size distribution of pedogenic magnetic particles in Chinese loess and its significance for pedogenesis," Journal of Geophysical Research: Solid Earth, vol. 110, no. B11, 2005.

[12] P. Gautam, U. Blaha, and E. Appel, "Integration of magnetic properties and heavy metal chemistry to quantify environmental pollution in urban Soils, Kathmandu, Nepal," in Proceedings of the Extended Abstract: 19th Himalaya- Karakoram -Tibet Workshop, Niseko, Japan, 2004.

[13] B. A. Maher, "Characterisation of soils by mineral magnetic measurements," Physics of the Earth and Planetary Interiors, vol. 42, no. 1-2, pp. 76-92, 1986.

[14] A. Sadiki, A. Faleh, A. Navas, and S. Bouhlassa, "Using magnetic susceptibility to assess soil degradation in the Eastern Rif, Morocco," Earth Surface Processes and Landforms, vol. 34, no. 15, pp. 2057-2069, 2009.

[15] M. Hanesch and R. Scholger, "Mapping of heavy metal loadings in soils by means of magnetic susceptibility measurements," Environmental Geology, vol. 42, no. 8, pp. 857-870, 2002.

[16] S. G. Lu, S. Q. Bai, and Q. F. Xue, "Magnetic properties as indicators of heavy metals pollution in urban topsoils: a case study from the city of Luoyang, China," Geophysical Journal International, vol. 171, no. 2, pp. 568-580, 2007.

[17] S. LU and S. BAI, "Magnetic Characterization and Magnetic Mineralogy of the Hangzhou Urban Soils and Its Environmental Implications," Chinese Journal of Geophysics, vol. 51, no. 3, pp. 549-557, 2008.

[18] B. A. Maher, "Magnetic properties of modern soils and quaternary loessic paleosols: Paleoclimatic implications," Palaeogeography, Palaeoclimatology, Palaeoecology, vol. 137, no. 1-2, pp. 2554, 1998.

[19] M. Hanesch and R. Scholger, "The influence of soil type on the magnetic susceptibility measured throughout soil profiles," Geophysical Journal International, vol. 161, no. 1, pp. 50-56, 2005.

[20] K. Porsch, M. L. Rijal, T. Borch et al., "Impact of organic carbon and iron bioavailability on the magnetic susceptibility of soils," Geochimica et Cosmochimica Acta, vol. 128, pp. 44-57, 2014.
[21] M. Moukhchane, S. Bouhlassa, and A. Chalouan, "Approche cartographique et magnétique pour lidentification des sources de sédiments: cas du bassin versant Nakhla (Rif, Maroc)," Secheresse, vol. 9, pp. 227-232, 1998.

[22] S. J. Sangode, K. Vhatkar, S. K. Patil et al., "Magnetic susceptibility distribution in the soils of Pune metropolitan region: Implications to soil magnetometry of anthropogenic loading," Current Science, vol. 98, no. 4, pp. 516-527, 2010.

[23] T. Forster, M. E. Evans, and F. Heller, "The frequency dependence of low field susceptibility in loess sediments," Geophysical Journal International, vol. 118, no. 3, pp. 636-642, 1994.

[24] X. WANG, "Paleoclimatic significance of mineral magnetic properties of loess sediments in northeastern Qinghai-Tibetan Plateau," Chinese Science Bulletin, vol. 48, no. 19, p. 2126, 2003.

[25] R. Zhu, C. Deng, and M. J. Jackson, "A magnetic investigation along a NW-SE transect of the Chinese loess plateau and its implications," Physics and Chemistry of the Earth, Part A: Solid Earth and Geodesy, vol. 26, no. 11-12, pp. 867-872, 2001.

[26] Q. Chen, X. Liu, F. Heller et al., "Susceptibility variations of multiple origins of loess from the Ily Basin (NW China)," Chinese Science Bulletin, vol. 57, no. 15, pp. 1844-1855, 2012.

[27] R. Egli, F. Florindo, and A. P. Roberts, "Introduction to Magnetic iron minerals in sediments and their relation to geologic processes, climate, and the geomagnetic field," Global and Planetary Change, vol. 110, pp. 259-263, 2013. 

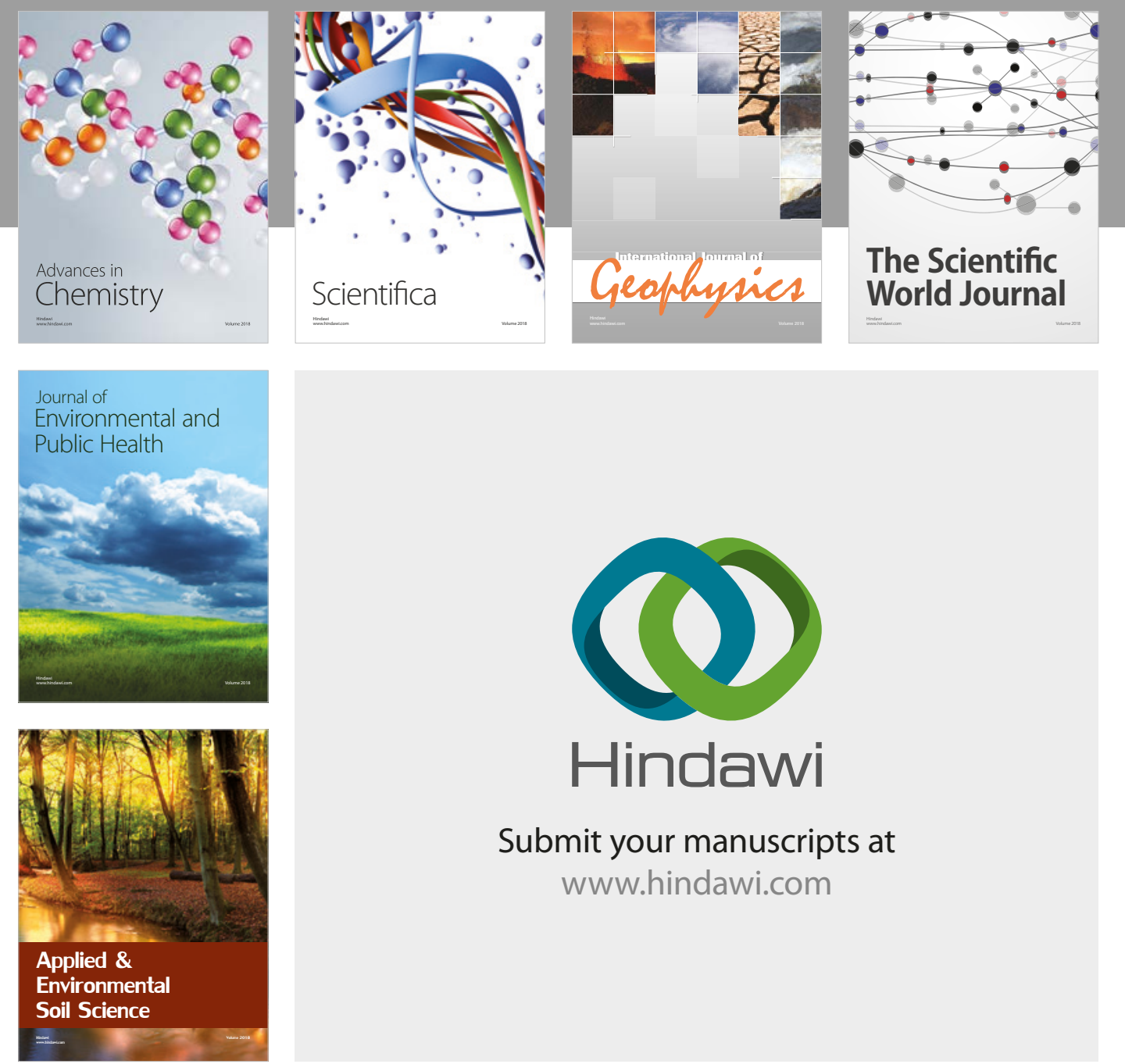

The Scientific

\section{World Journal}
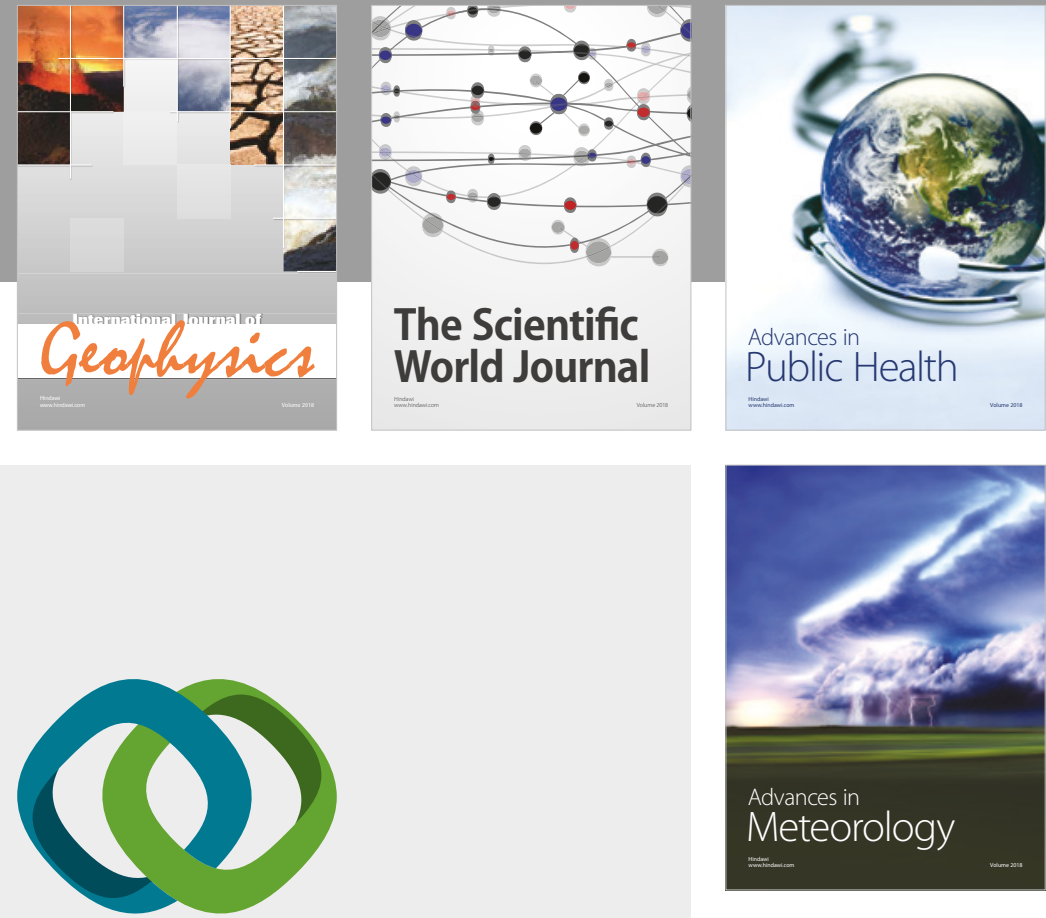

Advan

Public Health

\section{Hindawi}

Submit your manuscripts at

www.hindawi.com
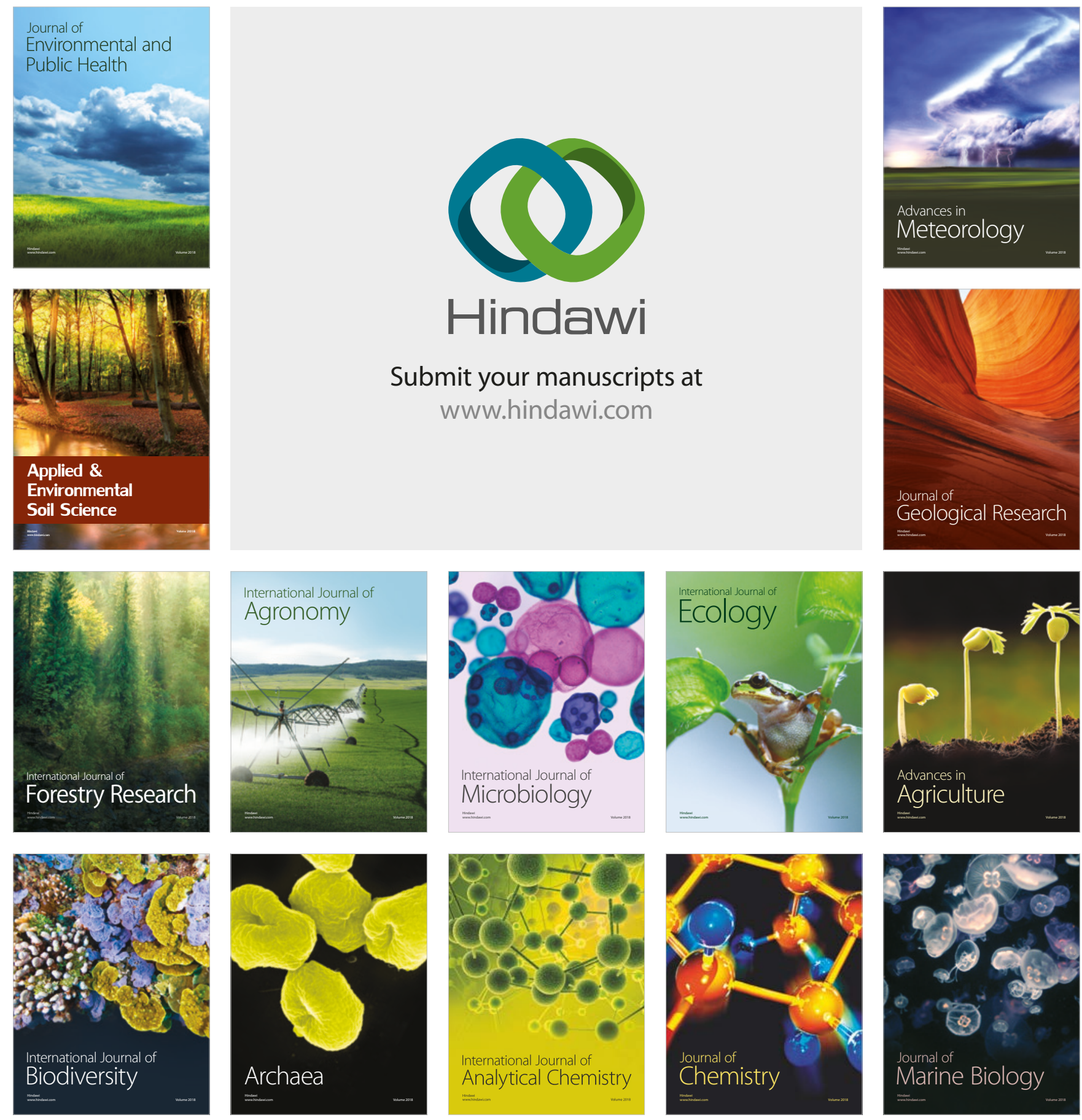